\title{
SOCIAL SECURITY INVESTMENT \\ IN EQUITIES I: LINEAR CASE
}

\author{
Peter Diamond \\ John Geanakoplos
}

Working Paper 7103

http://www.nber.org/papers/w7103

\author{
NATIONAL BUREAU OF ECONOMIC RESEARCH \\ 1050 Massachusetts Avenue \\ Cambridge, MA 02138 \\ April 1999
}

The views expressed herein are those of the authors and do not necessarily reflect the views of the National Bureau of Economic Research.

( 1999 by Peter Diamond and John Geanakoplos. All rights reserved. Short sections of text, not to exceed two paragraphs, may be quoted without explicit permission provided that full credit, including ${ }^{(}$notice, is given to the source. 
Social Security Investment in Equities I: Linear Case

Peter Diamond and John Geanakoplos

NBER Working Paper No. 7103

April 1999

JEL No. H55, E66, O41

\begin{abstract}
Social Security trust fund portfolio diversification to include some equities reduces the equity premium by raising the safe real interest rate. This requires changes in taxes. Under the hypothesis of constant marginal returns to risky investments, trust fund diversification lowers the price of land, increases aggregate investment, and raises the sum of household utilities, suitably weighted. It makes workers who do not own equities on their own better off, though it may hurt some others since changed taxes and asset values redistribute wealth across contemporaneous households and across generations. In our companion paper we reconsider the effects of diversification when there are decreasing marginal returns to safe and risky investment.

Our analysis uses a two-period overlapping generations general equilibrium model with two types of agents, savers and workers who do not save. The latter represent approximately half of all workers who hold no equities whatsoever.
\end{abstract}

Peter Diamond

Department of Economics

MIT

Room E52-344

50 Memorial Drive

Cambridge, MA 02139

and NBER

pdiamond@mit.edu
John Geanakoplos

Cowles Foundation

Yale University

30 Hillhouse Ave.

New Haven, CT 06520

john.geanakopolos@yale.edu 
April, 1999

ssfin final.doc

Social Security Investment in Equities I: Linear Case

Peter Diamond and John Geanakoplos ${ }^{1}$

Among the elderly, Social Security income is distributed very differently than private pension and asset income. ${ }^{2}$ For the bottom quintile of the income distribution, 81 percent of income comes from Social Security, while only 6 percent is from pensions plus income from assets. For the top quintile, 23 percent comes from Social Security, while 46 percent is from pensions and assets - dramatically different percentages. Similarly, there are great differences in saving and investing among current workers. Among all those who were paying social security taxes in 1995, fully 59\% held no stock, either directly or through pension plans. Even among those between 45 and 54 years of age, 50\% held no stock, directly or indirectly. ${ }^{3}$ These differences have important implications for the proposal to invest part of Social Security trust fund reserves in private securities.

This paper explores the equilibrium impact of social security trust fund portfolio diversification to include private securities. We evaluate the effects on relative prices, on welfare, and on investment. We use an overlapping-generations model with two types of representative agents, one of which does no saving (except through social security) and the other of which saves and adjusts her private portfolio in response to changes in rates of return (and, for simplicity is assumed not to be covered by social security). We refer to the two types of agents as workers and savers. In order to keep the analysis simple, social security is modeled as if it were a defined contribution system. Thus the analysis, although described in terms of trust fund investment, would hold equally well for social security individual accounts following the same investment strategy. The differences between defined benefit and defined contribution systems as distributors of rate-of-return risk have been explored in OLG models with a single representative agent. ${ }^{4}$ This paper is meant to complement those studies. There is a brief discussion of modeling a defined benefit plan in Section 9.

Our major finding is that trust fund portfolio diversification into equities has substantial real effects, including the potential for significant welfare improvements. Diversification raises the sum total of utility in the economy if household utilities are weighted so that the marginal utility of a dollar today is the same for every household. The potential welfare gains come from the presence of workers who do not invest their savings on their own.

If relative prices remain constant after diversification, as they would if there were constant marginal returns to all kinds of investment, then this represents a (weak) Pareto gain, since no households would lose and the workers would gain. Moreover, in this case expected output increases.

In this paper we concentrate on a tractable special case in which there are constant marginal returns in short-term risky investments, but no safe real investment. In this case, diversification changes the safe rate of interest, leaving the (expected) risky rate of return unchanged. Diversification still achieves a (weak) Pareto gain provided the marginal responses of taxes to interest rate changes match

\footnotetext{
${ }^{1}$ The authors are grateful to Saku Aura for research assistance, to Alicia Munnell, Jim Poterba and Antonio Rangel for comments, and to the National Science Foundation for research support under grant SBR-9618698.

${ }^{2}$ See Mitchell and Moore (1997), Social Security Administration (1996).

${ }^{3}$ Quoted in Geanakoplos, Mitchell, and Zeldes [1999]. See Kennickell, Starr-McCluer, and Sunden [1997] and Ameriks and Zeldes (in progress).

${ }^{4}$ See, for example, Bohn (1997, 1998), Diamond, (1997).
} 
debt holdings, and there are no long-lived assets. Without these assumptions, however, diversification may involve redistributions within or across cohorts, so that a Pareto gain might require additional policy steps.

Without long-lived assets and assuming that savers bear at least as large a share of taxes as of interest receipts, diversification increases the safe rate of interest, reducing the equity premium, since the expected risky rate of return stays the same (given the assumption of constant marginal returns). In this case diversification also increases aggregate investment, assuming normality of demands. An increase in the safe rate, however, increases government interest payments on its debt and forces a change in taxes. Given our hypothesis that savers pay more in taxes than they receive in interest payments on their government debt, the increase in taxes hurts savers. The fall in the equity premium also reduces the apparent advantage to diversifying the social security trust fund, but does not alter the conclusion that at least for small investments in equities, it raises the welfare of the workers. Moreover, the increase in the bond rate of return actually improves the returns for the trust fund assets remaining in bonds, and thus brings a second benefit to workers, provided their tax increase is not larger.

If, in addition, there are infinitely-lived assets like land (with the same risk characteristics) as well as the one-period assets, diversification still increases aggregate investment and raises the safe rate of interest. The rise in the safe interest rate reduces the price of land, redistributing wealth from the elderly, who hold the long-lived assets at the time of implementation of the policy, to later cohorts who buy the land. The welfare effect of diversification on young savers is now ambiguous, since young savers are likely to pay more income taxes due to the government's increased debt burden while gaining from the fall of land prices.

Land prices unambiguously fall because of our assumption of constant returns in the risky sector. In our companion paper, where we permit decreasing returns, we find that this result is often reversed, depending on the elasticity of marginal returns in the risky and safe sectors of production. ${ }^{5}$ To illustrate how this could happen, we consider here a model with constant marginal returns in short-term safe real investment but no short-term risky investment. In this case the price of risky land rises, reversing the direction of redistribution across cohorts.

Our analysis bears directly on assertions that Social Security Trust Fund investment in equities is not of value to the economy, assertions which do not recognize the issues of income distribution and risk bearing within a diverse cohort. ${ }^{6}$ This paper demonstrates that it is not adequate to consider trust fund policy in a representative agent model. Moreover, the analysis is relevant for assertions of those who consider only the potential return on individual accounts, ignoring the unfunded obligations of social security, the riskiness of equity investments, and the general equilibrium effects. ${ }^{7}$

\footnotetext{
${ }^{5}$ The assumptions in this paper permit analysis of a single endogenous rate of return. In the companion paper, we analyze models where the safe rate of interest and the expected risky rate of return are simultaneously endogenous.

6 See, for example, Financial Economists' Roundtable (1998), Greenspan (1997). Greenspan has testified: “As I have argued elsewhere, unless national savings increases, shifting social security trust funds to private securities, while likely increasing income in the social security system, will, to a first approximation, reduce non-social security retirement income to an offsetting degree. Without an increase in the savings flow, private pension and insurance funds, among other holders of private securities, presumably would be induced to sell higher-yielding stocks and private bonds to social security retirement funds in exchange for lower yielding US treasuries. This could translate into higher premiums for life insurance and lower returns on other defined contribution retirement plans. This would not be an improvement to our overall retirement system."

${ }^{7}$ For assertions that are subject to this criticism, see Forbes (1996) and Moore (1997). These points are made in the two papers by Geanakoplos, Mitchell, and Zeldes [1998, 1999]. The second of those papers also tried to quantify the welfare gains from social security investments in equities stemming from the presence of workers who could not save. Neither of those papers, however, had an explicit model with uncertainty in which all the general equilibrium effects of diversification could be accounted for.
} 
We introduce the model in sections 1-3. In section 4, we analyze the model in which there are constant marginal returns to all investments. In section 5, we analyze the effects of diversification when there are constant marginal returns to risky capital, and there are no safe productive investments. In sections 6 and 7 we add land. In section 8 we show that some of our conclusion about the price of land is reversed if we assume constant marginal returns in safe investments and no possibility for additional risky investments. Section 9 indicates how the model could be extended to allow for defined benefits, and section 10 contains concluding remarks.

\section{Technology}

We assume a linear technology to avoid the complications of feedbacks of investment rates on wages and rates of return to productive investments. There are (nonstochastic) endowments for young consumers, which can be interpreted as earnings from inelastically supplied labor. There are one or two investment opportunities in the economy. The safe investment, if it exists, produces $\mathrm{R}_{0} \mathrm{~K}_{0}$ in the period following an investment of $\mathrm{K}_{0}$, with no durability in the capital. The risky investment produces $\mathrm{RK}$ in the period following an investment of $\mathrm{K}$, also with no durability in the capital. For convenience, we assume the risky return to be independently and identically distributed each period. We assume that the returns to the real assets are such that both risky and safe assets are held in equilibrium when the safe asset exists. Starting with Section VI, we add infinitely-lived real assets to the model.

\section{Consumers}

To bring out most clearly the difference between social security covered workers and wealth holders, we follow an older literature and assume there are workers who do not save and savers who are not covered by social security; that is, two representative agents in each cohort. We assume that each worker receives $\mathrm{w}$ in the first period of life, with each saver receiving $\mathrm{W}$.

We assume no population growth and normalize the population so that there is a unit measure of (identical) savers and a measure of size $\mathrm{n}$ of (identical) workers. The representative saver maximizes expected lifetime utility of consumption, taking prices as given. Expected lifetime utility, $\mathrm{V}$, is equal to $\mathrm{U}_{1}\left[\mathrm{C}_{1}\right]+\mathrm{E}\left\{\mathrm{U}_{2}\left[\mathrm{C}_{2}\right]\right\}$, with $\mathrm{U}_{\mathrm{i}}$ concave. These consumers divide exogenous first period wealth, $\mathrm{W}$, among consumption and (up to) three assets - government bonds, B, and two types of capital, $\mathrm{K}_{0}$, which is the safe asset, and $\mathrm{K}$, which is the risky asset. In addition, the savers pay taxes, $\mathrm{T}$, in the second period. ${ }^{8}$ Thus, we denote expected utility maximization for the representative saver by:

$$
\begin{aligned}
& \mathrm{V}=\mathrm{Max} \mathrm{U}_{1}\left[\mathrm{C}_{1}\right]+\mathrm{E}\left\{\mathrm{U}_{2}\left[\mathrm{C}_{2}\right]\right\} \\
& \text { s. t. } \mathrm{W}=\mathrm{C}_{1}+\mathrm{B}+\mathrm{K}_{0}+\mathrm{K} \\
& \mathrm{C}_{2}=(1+\mathrm{r}) \mathrm{B}+\mathrm{R}_{0} \mathrm{~K}_{0}+\mathrm{RK}-\mathrm{T},
\end{aligned}
$$

where the rate of return, $\mathrm{R}$, is random, but taxes are not, as of the time of first period decisions. If the safe real asset does not exist, then $\mathrm{K}_{0}$ is constrained to be zero. If the safe real asset exists and is held in equilibrium, then $1+r$ is equal to $\mathrm{R}_{0}$ since the government bond and the safe real asset are perfect substitutes.

\footnotetext{
${ }^{8}$ Taxes are used to pay interest. By collecting taxes in the second period of life, they are paid back to the same cohort they are collected from. Collecting taxes in the first period instead would be equivalent to changing the level of government debt outstanding.
} 
Consumer choice can be viewed in terms of three (composite) goods - first-period consumption and safe and risky second-period consumption. ${ }^{9}$ We can restate the consumer choice problem in terms of these three goods, which we denote as $\mathrm{C}_{1}, \mathrm{~J}$ and $\mathrm{K}$. With first-period consumption as numeraire, the price of second-period safe consumption, $\mathrm{p}_{\mathrm{J}}$, is equal to $1 /(1+\mathrm{r})$. The price of second-period risky consumption is always one and is suppressed in the notation. We now restate the consumer choice problem as:

$$
\begin{gathered}
\mathrm{V}=\operatorname{Max} \mathrm{U}_{1}\left[\mathrm{C}_{1}\right]+\mathrm{E}\left\{\mathrm{U}_{2}[\mathrm{~J}+\mathrm{RK}]\right\} \\
\text { s. t. } \mathrm{C}_{1}+\mathrm{p}_{\mathrm{J}} \mathrm{J}+\mathrm{K}=\mathrm{W}-\mathrm{p}_{\mathrm{J}} \mathrm{T}
\end{gathered}
$$

We denote the demand for first period consumption as a function of the price of second-period safe consumption and net lifetime wealth by $C^{*}\left[p_{J}, I\right]=C^{*}\left[p_{J}, W-T /(1+r)\right]$, which is equal to $C^{*}\left[p_{J}, W-p_{J} T\right]$. Similarly, we denote the demand for risky assets by $K^{*}\left[p_{J}, I\right]=K^{*}\left[p_{J}, W-p_{J} T\right]$ and the demand for second-period safe consumption by $J^{*}\left[p_{J}, I\right]=J^{*}\left[p_{J}, W-p_{J} T\right]$. We focus on these variables since optimal consumption is unchanged if $\mathrm{p}_{\mathrm{J}}$ and $\mathrm{W}-\mathrm{p}_{\mathrm{J}} \mathrm{T}$ are unchanged. However, the holding of bonds that supports this consumption depends on $\mathrm{W}$ and $\mathrm{p}_{\mathrm{J}} \mathrm{T}$ separately, since second period consumption depends on $\mathrm{B}(1+\mathrm{r})$ $\mathrm{T}$, as can also be seen by looking at the first order conditions for the savings and portfolio decisions in equation (3): ${ }^{10}$

$$
\begin{aligned}
& \mathrm{U}_{1}^{\prime}\left[\mathrm{C}_{1}\right]=\mathrm{E}\left\{\mathrm{U}_{2}^{\prime}\left[\mathrm{C}_{2}\right](1+\mathrm{r})\right\}=\mathrm{E}\left\{\mathrm{U}_{2}^{\prime}\left[\mathrm{C}_{2}\right] \mathrm{R}\right\} ; \\
& \mathrm{U}_{1}^{\prime}\left[\mathrm{C}^{*}\right]=\mathrm{E}\left\{\mathrm{U}_{2}^{\prime}\left[\left(\mathrm{W}-\mathrm{C}^{*}-\mathrm{K}^{*}\right)(1+\mathrm{r})+\mathrm{K}^{*} \mathrm{R}-\mathrm{T}\right](1+\mathrm{r})\right\}=\mathrm{E}\left\{\mathrm{U}_{2}^{\prime}\left[\left(\mathrm{W}-\mathrm{C}^{*}-\mathrm{K}^{*}\right)(1+\mathrm{r})+\mathrm{K}^{*} \mathrm{R}-\mathrm{T}\right] \mathrm{R}\right\} .
\end{aligned}
$$

We assume that all three of first period consumption, and demand for safe and risky assets are normal goods. The intertemporally additive structure of preferences ensures that first period consumption is a normal good. A sufficient condition for normality of all three goods is that second period utility displays decreasing absolute risk aversion and increasing relative risk aversion (Aura, Diamond and Geanakoplos, 1999).

In contrast, we model workers, who also have two-period lifetimes, as nonsavers. Each worker earns a wage, $w$, in the first period (with inelastically supplied labor), pays payroll taxes $t_{w}$ in the first period, and consumes $w-t_{\mathrm{w}}{ }^{11}$ In the second period, workers consume social security benefits, $\mathrm{b}$, which may be random, less taxes $\mathrm{t}$. We denote lifetime utility by $\mathrm{v}$ and note that it satisfies:

$$
v=u_{1}\left[w-t_{w}\right]+E\left\{u_{2}[b-t]\right\}
$$

We distinguish two sources of taxes since the payroll tax will be used for social security, while the second period tax will be used to pay part of the interest on the government debt outstanding.

\section{Government}

\footnotetext{
${ }^{9}$ Since all trading and production opportunities can be written in terms of these composite commodities, analysis of equilibrium can be done in these terms. Written in this form, the usual properties of compensated demands hold for the vector of consumptions. On the properties of compensated demands in the presence of uncertainty, see Diamond and Yaari, 1972 and Fischer, 1972. Moreover, analysis can be done in this form without the assumption of expected utility.

${ }^{10}$ The demand for bonds depends on both lifetime wealth and the need to save to pay second-period taxes, which are nonstochastic and so matched by bond holdings. When analyzing the interest rate, the demand for risky assets exactly maps into the demand for risky second-period consumption. However, the demand for bonds depends on both the demand for safe secondperiod consumption and the relationship between bonds and safe second-period consumption, which depends on the interest rate, as well as the need to pay taxes.

${ }^{11}$ The lack of randomness in w, and so lack of randomness in benefits (given the other assumptions) implies that workers are risk neutral for the first derivative amount of any risk in retirement benefits received. What is crucial is not risk neutrality, but an expected utility gain given the risk premium in an economy where they bear no capital risk.
} 
It is assumed that each period the government issues one-period debt with a value of G, of which $\mathrm{F}$ is held by the trust fund and B is held privately by savers. The interest payments on this debt are financed by taxes on older workers and older savers, with the principal rolled over to preserve the debt outstanding.

$$
\mathrm{T}_{\mathrm{t}}+\mathrm{nt}_{\mathrm{t}}=\mathrm{Gr}_{\mathrm{t}-1}
$$

where taxes collected in period $t$ are used to pay interest at rate $r_{t-1}$ on debt issued in period $t-1$. We assume that taxes are divided in the proportions a and 1-a, implying that

(6) $\mathrm{T}_{\mathrm{t}}=\mathrm{aGr}_{\mathrm{t}-1}$.

In addition to holding $\mathrm{F}$ of government debt, the trust fund is assumed to hold $\mathrm{K}^{\mathrm{f}}$ of the risky real asset (possibly equal to zero at the outset). Denoting the value of the trust fund by $\mathrm{F}_{0}$, we have

(7) $\mathrm{F}+\mathrm{K}^{\mathrm{f}}=\mathrm{F}_{0}$.

Given the need to maintain the trust fund, payroll taxes and social security benefits satisfy:

$$
b_{t}=t_{w}+\left(r_{t-1} F+(R-1) K^{f}\right) / n
$$

Thus the expected utility of workers, v, satisfies:

$$
\begin{aligned}
\mathrm{v} & =\mathrm{u}_{1}\left[\mathrm{w}-\mathrm{t}_{\mathrm{w}}\right]+\mathrm{E}\left\{\mathrm{u}_{2}\left[\mathrm{t}_{\mathrm{w}}-\mathrm{t}+\left(\mathrm{r}_{\mathrm{t}-1} \mathrm{~F}+(\mathrm{R}-1) \mathrm{K}^{\mathrm{f}}\right) / \mathrm{n}\right]\right\} \\
& =\mathrm{u}_{1}\left[\mathrm{w}-\mathrm{t}_{\mathrm{w}}\right]+\mathrm{E}\left\{\mathrm{u}_{2}\left[\mathrm{t}_{\mathrm{w}}-\mathrm{t}+\left(\mathrm{r}_{\mathrm{t}-1} \mathrm{~F}_{0}+\left(\mathrm{R}-1-\mathrm{r}_{\mathrm{t}}\right) \mathrm{K}^{\mathrm{f}}\right) / \mathrm{n}\right]\right\} .
\end{aligned}
$$

The wage and the payroll tax rate are assumed to be constant over time; the retirement benefits, however are free to vary, and will if the rates of return earned on the trust fund holdings vary. Similarly, the second-period tax will change if the interest rate on government debt changes.

Equilibrium requires that the supply of government bonds is equal to the demand for bonds by the trust fund, F, plus the demand for bonds by savers, B:

$$
\mathrm{G}=\mathrm{F}+\mathrm{B} \text {. }
$$

This closes the model, so we can turn now to comparative static analyses. We shall analyze the effect on equilibrium of a change in trust fund investment in risky assets: $\mathrm{dK}^{\mathrm{f}}=-\mathrm{dF}>0$.

\section{One-period assets, safe investment available}

We assume the economy has two physical assets, one safe and one risky, each providing constant marginal returns, as described in section I. In equilibrium, the interest rate on government bonds must be equal to the (exogenously fixed) rate of return on the safe asset. Changing trust fund investments, by selling some debt to the savers and investing more in the risky asset, has no effect whatsoever on the savers as long as their holdings of safe real capital remain positive - they substitute government debt for safe real capital, which is a perfect substitute, holding their risky investment constant. Since the interest rate does not change, second-period taxes do not change. If the trust fund initially has only a small 
amount of the risky asset, this policy is a (weak) Pareto gain - savers are not affected and workers gain since the workers are not risk averse for the first bit of investment in risky assets. That is, if $\mathrm{K}^{\mathrm{f}}$ is small, the workers are less risk averse at the margin than the savers (who are assumed to be holding some of both assets, and so indifferent at the margin between the two assets). The workers will therefore gain in expected utility from substituting a small amount of risky stock for the same value of riskless bonds.

While aggregate investment does not change, aggregate risky investment increases and aggregate safe investment decreases. Thus, aggregate expected output increases since the expected return on risky investment exceeds that on safe investment. This analysis would apply as well to an open economy with a perfectly elastic international demand for government debt.

By the same logic, further increases in risky asset holdings would also be weak Pareto gains until the optimal portfolio for workers was reached, unless the saver's holdings of the safe real investment reached zero first. In the latter case, we would no longer have the interest rate on government debt determined by the technological return on the safe asset and would need to change the analysis, as we do below.

In contrast to the Pareto gain in this two-agent model with some non-savers, in a representative agent model with rational savers, a change in trust fund portfolio policy would have no effects at all. This contrast continues to hold in the later models analyzed here. ${ }^{12}$

Next we turn to a setting where the lack of a safe investment in equilibrium implies that the endogenous rate of interest on government debt is affected by trust fund investment policy.

\section{Equilibrium with one-period assets, no safe real investment}

If there are constant marginal returns to risky investments and no safe real asset, then the interest rate on government debt is endogenous and is determined by the supply of and demand for bonds. In equilibrium, any change in the interest rate requires a change in taxes to cover interest costs. The only endogenous variable is the safe interest rate, or the price of safe second-period consumption, denoted by $\mathrm{p}_{\mathrm{J}}$. Noting that the demand for bonds is first-period wealth minus the sum of demand for first-period consumption and demand for risky assets, and using (6) and the relationship between the price of second period consumption and the interest rate, we can write market clearance (10) as:

$$
\begin{aligned}
G-F_{0}+K^{f} & =W-C^{*}\left[p_{J}, W-p_{J} T\right]-K^{*}\left[p_{J}, W-p_{J} T\right] \\
& =W-C^{*}\left[p_{J}, W-p_{J} a r G\right]-K^{*}\left[p_{J}, W-p_{J} a r G\right] \\
& =W-C^{*}\left[p_{J}, W-\left(1-p_{J}\right) a G\right]-K^{*}\left[p_{J}, W-\left(1-p_{J}\right) a G\right] .
\end{aligned}
$$

Thus, we have a single equation to determine the endogenous price of second-period safe consumption. Note that with $G, F_{0}$, and $\mathrm{W}$ all fixed, the response of aggregate investment, $\mathrm{K}+\mathrm{K}^{\mathrm{f}}$, to portfolio policy is minus the response of consumption of savers, $C^{*}$.

\section{Expected utility}

We want to examine the effect on equilibrium of an increase in trust fund holdings of risky assets, holding constant the level of the trust fund. This will change the supply of bonds available to the savers.

\footnotetext{
12 This has been noted by Smetters, 1997.
} 
In addition, if the shares of marginal second-period taxes paid by savers and workers do not match their shares in the holding of government debt (directly by savers and indirectly through social security for workers), there is a redistribution between them.

Before examining the change in the interest rate, we begin by considering the effect of an interest rate change on the expected lifetime utility of the representative saver. Since the economy adjusts fully to long-run equilibrium in a single period, we can write expected utility of a cohort of savers as a function of trust fund asset policy as:

$$
\mathrm{V}=\mathrm{U}_{1}\left[\mathrm{C}^{*}\right]+\mathrm{E}\left\{\mathrm{U}_{2}\left[\left(\mathrm{~W}-\mathrm{C}^{*}-\mathrm{K}^{*}\right)(1+\mathrm{r})+\mathrm{RK} \mathrm{K}^{*}-\mathrm{T}\right]\right\}
$$

where $\mathrm{r}$ is the endogenous interest rate. By the envelope theorem, the changes in $\mathrm{r}$ and $\mathrm{T}$ have a direct impact on expected utility, but the indirect changes drop out. Thus the change in lifetime expected utility from an increase in trust fund holdings of capital (and so a decrease in trust fund holdings of government debt) satisfies:

$$
\begin{aligned}
\mathrm{dV} / \mathrm{dK}^{\mathrm{f}} & =\mathrm{E}\left\{\mathrm{U}_{2}{ }^{\prime}\right\}\left(\mathrm{B}\left(\mathrm{dr} / \mathrm{dK}^{\mathrm{f}}\right)-\mathrm{dT} / \mathrm{dK}^{\mathrm{f}}\right) \\
& =\mathrm{E}\left\{\mathrm{U}_{2}^{\prime}\right\}\left(\mathrm{B}\left(\mathrm{dr} / \mathrm{dK} \mathrm{K}^{\mathrm{f}}\right)-\mathrm{aG}\left(\mathrm{dr} / \mathrm{dK} \mathrm{f}^{\mathrm{f}}\right)\right) \\
& =\mathrm{E}\left\{\mathrm{U}_{2}^{\prime}\right\}(\mathrm{B}-\mathrm{aG})\left(\mathrm{dr} / \mathrm{dK} \mathrm{K}^{\mathrm{f}}\right) .
\end{aligned}
$$

That is, savers lose from any increase in the government bond interest rate to the extent that their relative holdings of government debt are less than their share of marginal taxes to cover interest costs. If a equals $\mathrm{B} / \mathrm{G}$, then savers are not affected by a marginal change in trust fund investment policy and we again have a (weak) Pareto gain, as in the model above with a safe real asset. ${ }^{13}$

Workers are affected by trust fund investment and by the impact of the interest rate on benefits and taxes. Differentiating expected lifetime utility of workers, we have:

$$
\begin{aligned}
\mathrm{dv} / \mathrm{dK}^{\mathrm{f}} & =\mathrm{E}\left\{\mathrm{u}_{2}{ }^{\prime}\left((\mathrm{R}-1-\mathrm{r}) / \mathrm{n}-\mathrm{dt} / \mathrm{dK}^{\mathrm{f}}+\mathrm{F}\left(\mathrm{dr} / \mathrm{dK}^{\mathrm{f}}\right) / \mathrm{n}\right)\right\} \\
& =\mathrm{E}\left\{\mathrm{u}_{2}{ }^{\prime}\left(\mathrm{R}-1-\mathrm{r}+(\mathrm{F}-(1-\mathrm{a}) \mathrm{G})\left(\mathrm{dr} / \mathrm{dK} \mathrm{K}^{\mathrm{f}}\right)\right\} / \mathrm{n}\right. \\
& =\mathrm{E}\left\{\mathrm{u}_{2}{ }^{\prime}(\mathrm{R}-1-\mathrm{r})\right\} / \mathrm{n}-\mathrm{E}\left\{\mathrm{u}_{2}{ }^{\prime}\right\}(\mathrm{B}-\mathrm{aG})\left(\mathrm{dr} / \mathrm{dK}^{\mathrm{f}}\right) / \mathrm{n} .
\end{aligned}
$$

Diversification affects workers through two channels. As was the case with a safe real asset, the expected utility of workers increases from bearing some risk if they were bearing none before diversification. In addition, the direct effect on workers from the change in the interest rate has the opposite sign from its effect on savers, as can be seen by comparing (13) and (14). If a is equal to $\mathrm{B} / \mathrm{G}$, then this effect is zero and we have only the gain from improved risky investment.

The equity premium is equal to the difference between the expected return on the risky investment and the return on the safe investment, $E\{R\}-(1+r)$. With the equity premium determined by the portfolio choice of risk averse agents, it is positive in equilibrium. As long as the equity premium is positive, there is an expected utility gain to workers from diversification in a model where they bear no other risk, since then $E\left\{u_{2}{ }^{\prime}(R-1-r)\right\}=u_{2}{ }^{\prime} E\{R-1-r\}>0$. (This is the only benefit if $B=a G$.) This is a rigorous version of the argument for diversification made by those who point to the historical return on

\footnotetext{
${ }^{13}$ Actually, if $\mathrm{a}=\mathrm{B} / \mathrm{G}$, then savers obtain a second order benefit from trust fund diversification, assuming $\mathrm{dr} / \mathrm{dK}$ is not 0 . Except for old savers and old workers at the time of the diversification, everybody in every generation is better off after diversification.
} 
equities compared to bonds. We can see that this argument only has force to the extent that workers' risk aversion and their income in old age is such that, in the absence of diversification, they are relatively less risk averse than savers on the margin. At the point where the trust fund holds no stock, it is very likely that workers would be better off by investing in equity. The converse would hold only if it would be optimal for workers just starting to save to hold a portfolio with no stocks at all. In considering the optimal level of diversification, we note that since social security benefits become more correlated with stock returns because of diversification, the welfare benefits to further diversification decline. The mix in the social security covered population between savers and nonsavers also affects the importance of diversification since savers can adjust the remainder of their portfolio to counterbalance the riskiness of the trust fund portfolio.

Denoting the social evaluation of the marginal utility of a worker relative to that of a saver by $\mathrm{m}$, the impact on a social welfare function (SWF) equal to the weighted sum of individual expected utilities satisfies:

$$
\begin{aligned}
\mathrm{dSWF} / \mathrm{dK}^{\mathrm{f}} & =\mathrm{nmdv} / \mathrm{dK}^{\mathrm{f}}+\mathrm{dV} / \mathrm{dK}^{\mathrm{f}} \\
& =\mathrm{mE}\left\{\mathrm{u}_{2}{ }^{\prime}(\mathrm{R}-\mathrm{r}-1)\right\}-\mathrm{E}\left\{\mathrm{mu}_{2}{ }^{\prime}-\mathrm{U}_{2}{ }^{\prime}\right\}(\mathrm{B}-\mathrm{aG}) \mathrm{dr} / \mathrm{dK}^{\mathrm{f}} .
\end{aligned}
$$

Thus there is a direct utility gain from improved risk bearing and a redistributive term, which vanishes if a equals $\mathrm{B} / \mathrm{G}$. If there is an income distribution change from the transfer between savers and workers, its effect depends on the direction of transfer and the sign of $E\left\{m u_{2}^{\prime}-U_{2}{ }^{\prime}\right\}$. In particular, if we choose $m$ so that one unit of the consumption good gives the same marginal utility to every agent, then the redistribution term drops out and total utility is increased by diversification.

In the next section we shall show that whenever $\mathrm{B} \leq \mathrm{aG}$, and demand for risky assets increases in wealth, then $\mathrm{dr} / \mathrm{dK}^{\mathrm{f}}>0$. We summarize by saying:

Proposition 1: Suppose there are no long-lived assets, that the share of taxes of savers is at least as large as their share of bond holdings, $\mathrm{B} \leq \mathrm{aG}$, and that the demand for risky investment increase with wealth. Then, starting from a trust fund portfolio entirely in bonds, trust fund purchases of risky investment increase the sum total utility of all workers and savers, weighted so that each one has the same marginal utility of income of money at date 0 . In particular, diversification raises the utility of workers in every generation (except the original old, who are unaffected). If in addition, $\mathrm{B}=\mathrm{aG}$, then trust fund diversification also improves (up to second order) the utility of young savers in every generation. If instead, $\mathrm{B}<\mathrm{aG}$, then diversification (without any other policy changes) lowers the utility of young savers in every generation.

Assume that we start with a position of no risky assets in the trust fund, $\mathrm{K}^{\mathrm{f}}=0$, and shares in the financing of the interest on government debt that imply no redistribution, $\mathrm{B}=\mathrm{aG}$. If we consider a small discrete portfolio change toward risky assets by the trust fund, there is a (strong) Pareto gain, provided the change is small enough. As we change the shares of the debt held, the rise in the interest rate starts to be a redistribution from workers to savers. For a small enough change, the workers still have a gain from the improved portfolio and the savers gain from the change in the interest rate. ${ }^{14}$

\footnotetext{
${ }^{14}$ We have considered two different models with perfectly elastic and perfectly inelastic supplies of safe assets. We could consider an intermediate model with a downward-sloping demand by foreigners for government debt. This would give a change in the equilibrium interest rate that was between the two cases analyzed. In this case, the increase in the interest rate on government debt would involve increased payments abroad as well as transfers from taxpayers to trust fund beneficiaries.
} 


\section{Interest rate and aggregate savings}

It remains to examine the effect on the interest rate and on the level of aggregate savings. We have noted that the lifetime expected utility of savers is unaffected (up to first order) by this policy change when a equals $\mathrm{B} / \mathrm{G}$. Thus the response of the interest rate can be expressed in terms of compensated demand derivatives, as well as a term multiplied by $\mathrm{B}-\mathrm{aG}$. To calculate the compensated demands, we note that the level of second-period safe consumption is equal to $\mathrm{B}(1+\mathrm{r})-\mathrm{T}$, which equals $\mathrm{B}+\mathrm{r}(\mathrm{B}-\mathrm{aG})$.

The price of second-period safe consumption clears the government debt market, given by (11) above. Differentiating (11), we have:

$$
\begin{aligned}
\mathrm{dp}_{\mathrm{J}} / \mathrm{dK}^{\mathrm{f}} & =-1 /\left(\mathrm{C}_{\mathrm{p}}^{*}+\mathrm{C}^{*}{ }_{\mathrm{I}} \mathrm{G}+\mathrm{K}_{\mathrm{p}}^{*}+\mathrm{K}_{\mathrm{I}}^{*} \mathrm{aG}\right) \\
& =-1 /\left(\mathrm{C}_{\mathrm{p}}^{*}+\mathrm{K}_{\mathrm{p}}^{*}+(\mathrm{B}+\mathrm{r}(\mathrm{B}-\mathrm{aG}))\left(\mathrm{C}_{\mathrm{I}}^{*}+\mathrm{K}_{\mathrm{I}}^{*}\right)-(1+\mathrm{r})(\mathrm{B}-\mathrm{aG})\left(\mathrm{C}^{*}{ }_{\mathrm{I}}+\mathrm{K}_{\mathrm{I}}^{*}\right)\right) .
\end{aligned}
$$

The first three terms in the denominator are the compensated demands for $\mathrm{C}$ and $\mathrm{K}$. To preserve expected utility, the sum must have the opposite sign from the derivative of the compensated demand for safe second-period consumption, which is negative, since compensated own derivatives are negative. The last term in the denominator is the effect of redistribution between savers and workers. Assuming that firstperiod consumption and second-period risky consumption are normal goods and redistribution is from savers to workers $(\mathrm{B} \leq \mathrm{aG})$, then this term is positive as well. Thus, the derivative is negative, or, equivalently, the interest rate increases when the trust fund purchases risky assets instead of government debt. Note that our analysis holds for any $\mathrm{K}^{\mathrm{f}} \geq 0$.

We state this as:

Proposition 2: Assuming no long-lived assets, that the share of taxes of savers is at least as large as their share of bond holdings, and that the demand for risky investment increase with wealth, then, trust fund purchases of risky investment increase the interest rate on government debt.

We note that the intertemporally additive structure of preferences implies that demand for first-period consumption is normal and the assumption of decreasing absolute risk aversion in second-period utility would imply that the demand for risky assets increases with wealth.

To consider the impact of changing portfolio policy on aggregate savings, we need to determine the impact on the consumption of young savers, since the consumption of young workers does not change. From the analysis leading to (16), we note that the derivative of first-period consumption with respect to the price of second-period safe consumption (including the feedback through taxes) is

$$
\mathrm{dC}^{*} / \mathrm{dp}_{\mathrm{J}}=\mathrm{C}_{\mathrm{p}}^{*}+(\mathrm{B}+\mathrm{r}(\mathrm{B}-\mathrm{aG})) \mathrm{C}_{\mathrm{I}}^{*}-(1+\mathrm{r})(\mathrm{B}-\mathrm{aG}) \mathrm{C}_{\mathrm{I}}^{*} \text {. }
$$

The first two terms are the compensated cross elasticity of first-period consumption with respect to the price of second-period safe consumption. If the demand for safe second-period consumption is normal, then a rise in the price of safe second-period consumption (fall in the interest rate) increases the compensated demand for first period (Aura, Diamond, and Geanakoplos, 1999). The last term reflects the redistribution from savers to workers $(\mathrm{B} \leq \mathrm{aG})$ and is also positive with normality of demand for first period consumption.

We state this as: 
Proposition 3: Assuming no long-lived assets, that the share of taxes of savers is at least as large as their share of bond holdings and that the demand for bonds is increasing in wealth, then, trust fund purchases of risky investment increase aggregate real investment.

We note that the intertemporally additive structure of preferences implies that demand for first-period consumption is normal and the assumptions of decreasing absolute risk aversion and increasing relative risk aversion in second-period utility implies that the demand for safe second-period consumption is normal.

Complementing these propositions, we note that if an increase in the government interest rate redistributes from workers to savers, $\mathrm{B}>\mathrm{aG}$, then the interest rate may rise or fall.

\section{Adding Infinitely-lived Assets}

In the model above, no assets last more than one period. Thus the change in the interest rate does not redistribute wealth across generations. We now add two infinitely lived assets. We assume fixed quantities of both types of asset. We will refer to these assets as land. Each unit of safe land provides one unit of consumption, independent of the state of nature, in each period. ${ }^{15}$ Each unit of risky land produces the same (realized) output as one unit of the (contemporaneous) risky investment. Thus, we have not introduced any assets with new risk characteristics. We denote the supplies of the two assets by $\mathrm{L}_{0}$ and $\mathrm{L}$, their prices by $\mathrm{p}_{0}$ and $\mathrm{p}$. Because of the stationary structure of the economy, these prices are constant over time.

If a young saver buys one unit of safe land, it costs $\mathrm{p}_{0}$ and yields consumption in the second period (from output and resale) of $1+\mathrm{p}_{0}$. Since this is a perfect substitute for buying $\left(1+\mathrm{p}_{0}\right) /(1+\mathrm{r})$ units of the government bond, we have

$$
\mathrm{p}_{0}=\left(1+\mathrm{p}_{0}\right) /(1+\mathrm{r})
$$

or

$$
\mathrm{p}_{0}=1 / \mathrm{r}=\mathrm{p}_{\mathrm{J}} /\left(1-\mathrm{p}_{\mathrm{J}}\right)
$$

Similarly, by spending $\mathrm{p}$ on risky land, the consumer gets the dividend that can be purchased at a price of 1, (by investing in the short-lived risky asset) and the ability to sell the asset at price $p$, which has a current value of $\mathrm{p} /(1+\mathrm{r})$. Thus, by arbitrage, we have the equilibrium price satisfying:

$$
\mathrm{p}=1+\mathrm{p} /(1+\mathrm{r})
$$

or

$$
\mathrm{p}=(1+\mathrm{r}) / \mathrm{r}=1+1 / \mathrm{r}=1 /\left(1-\mathrm{p}_{\mathrm{J}}\right)
$$

Thus the prices of both kinds of land increase with the price of second-period safe consumption; equivalently, land prices decrease when the interest rate rises.

A rise in the safe interest rate will lower land prices, hurting the older generation holding the land at the time the policy is initiated, but, as we will see, this effect benefits all later generations of savers.

\footnotetext{
${ }^{15}$ This might be a fixed number of government consols, the interest on which is financed by taxation on successive generations.
} 
That is, the effect of the increased interest rate works through both tax-financed bond interest and infinitely-lived asset holdings. While the former may be offset by the tax increase, the latter is not, representing a transfer from the initial asset holders to all future generations of savers. Even though the government is shifting demand from bonds to risky assets, we shall show that the price of long-lived risky assets falls, since the rise in the interest rate is the only channel through which asset prices are affected.

\section{Equilibrium with one-period risky assets and infinitely-lived assets}

Adding land to the model outlined in sections I-III means extending the budget set described in (1) to include safe and risky land holdings, and augmenting the market clearing condition for bonds described in (10) to include market clearing in safe land and in risky land. Observe, however, that the one-period payoffs of land are a convex combination of the safe and risky payoffs from short-term production. Hence we can incorporate land into our model by using the formulation of the budget set given in (2) together with a modification of the bond market clearing equation (10), provided that we recognize the connection between land prices and the interest rate derived above. Once again we shall formulate the equilibrium condition as one equation in the one endogenous variable, the safe interest rate.

Spending on safe second-period consumption equals wealth I minus the sum of demand for firstperiod consumption and demand for risky assets. However, this spending is used to purchase safe land and the safe consumption coming from the later sale of risky land as well as bonds. The presence of land does not change the expected utility maximization problem of savers given in (2). It is just that they have several ways of acquiring the same patterns of second-period consumption. Thus the demand functions, $\mathrm{C}^{*}\left[\mathrm{p}_{\mathrm{J}}, \mathrm{W}-\mathrm{p}_{\mathrm{J}} \mathrm{T}\right]$ and $\mathrm{K}^{*}\left[\mathrm{p}_{\mathrm{J}}, \mathrm{W}-\mathrm{p}_{\mathrm{J}} \mathrm{T}\right]$ do not change, but $\mathrm{K}^{*}$ is now the demand for the sum of risky short-term investments and the one-period payoffs of risky land. For market clearance in the demand for bonds, we need to recognize that savers acquire safe future consumption by buying bonds, and both types of land. Thus, adapting (11) for the presence of infinitely-lived assets, and assuming that the trust fund does not hold any long-lived assets, we can write market clearance for bonds as:

$$
\begin{aligned}
G-F_{0}+K^{f} & =W-C^{*}\left[p_{J}, W-\left(1-p_{J}\right) a G\right]-K^{*}\left[p_{J}, W-\left(1-p_{J}\right) a G\right]-p_{0} L_{0}-(p-1) L \\
& =W-C^{*}\left[p_{J}, W-\left(1-p_{J}\right) a G\right]-K^{*}\left[p_{J}, W-\left(1-p_{J}\right) a G\right]-p_{J}\left(L_{0}+L\right) /\left(1-p_{J}\right),
\end{aligned}
$$

where we have used (19) and (21). Aggregate investment in short-lived production is government demand for real investment, $\mathrm{K}^{\mathrm{f}}$, plus the demand of savers for risky consumption, $\mathrm{K}^{*}$, minus the portion of that demand that is satisfied by purchasing risky land, L. Note that with $\mathrm{G}, \mathrm{F}_{0}, \mathrm{~W}$ and the quantities of land all fixed, the response of aggregate investment in risky short-term assets, $\mathrm{K}^{\mathrm{f}}+\mathrm{K}^{*}-\mathrm{L}$, to portfolio policy is minus the sum of the response of consumption of savers, $\mathrm{C}^{*}$, and the change in the value of total land, $\mathrm{p}_{0} \mathrm{~L}_{0}+\mathrm{pL}$.

Note also that the level of safe second-period consumption, $J$, is equal to $B(1+r)-T+\left(p_{0}+1\right) L_{0}+p L$ $=\mathrm{B}+\mathrm{r}(\mathrm{B}-\mathrm{aG})+\left(\mathrm{p}_{0}+1\right) \mathrm{L}_{0}+\mathrm{pL}$.

\section{Expected utility in a model with land}

If land prices go down in value, the old savers at the time of the trust fund diversification lose, ceteris paribus. Young savers gain, as do savers in every succeeding generation. In addition, we must also take into account the effect on taxes and bond payments as a result of a change in the safe interest rate, as we saw in the previous sections. Thus the expected utility of young savers can increase or decrease, depending on the balance between within cohort and across cohort redistributions. The level of optimized expected utility, given in (2), is affected by portfolio diversification by its effect on the price of safe second-period consumption and its effect on taxes. 


$$
\begin{aligned}
\mathrm{dV} / \mathrm{dK}^{\mathrm{f}} & =-\mathrm{U}_{1^{\prime}}\left(J\left(\mathrm{dp}_{\mathrm{J}} / \mathrm{dK}^{\mathrm{f}}\right)+\mathrm{d}\left(\mathrm{p}_{\mathrm{J}} \mathrm{T}\right) / \mathrm{dK}^{\mathrm{f}}\right) \\
& \left.=-\mathrm{E}\left\{\mathrm{U}_{2}^{\prime}\right\}(1+\mathrm{r})\left(\mathrm{B}(1+\mathrm{r})-\mathrm{T}+\left(\mathrm{p}_{0}+1\right) \mathrm{L}_{0}+\mathrm{pL}\right)\left(\mathrm{dp}_{\mathrm{J}} / \mathrm{dr}\right)\left(\mathrm{dr} / \mathrm{dK}^{\mathrm{f}}\right)+\mathrm{aG}\left(\mathrm{d}\left(\mathrm{p}_{\mathrm{J}} \mathrm{r}\right) / \mathrm{dr}\right)\left(\mathrm{dr} / \mathrm{dK}^{\mathrm{f}}\right)\right) \\
& \left.=\mathrm{E}\left\{\mathrm{U}_{2}{ }^{\prime}\right\}(1 /(1+\mathrm{r}))\left(\mathrm{B}(1+\mathrm{r})-\mathrm{aGr}+\left(\mathrm{p}_{0}+1\right) \mathrm{L}_{0}+\mathrm{pL}-\mathrm{aG}\right)\left(\mathrm{dr} / \mathrm{dK}^{\mathrm{f}}\right)\right) \\
& =. \mathrm{E}\left\{\mathrm{U}_{2}^{\prime}\right\}\left(\mathrm{B}-\mathrm{aG}+\mathrm{p}_{0}\left(\mathrm{~L}_{0}+\mathrm{L}\right)\right)\left(\mathrm{dr} / \mathrm{dK}^{\mathrm{f}}\right)
\end{aligned}
$$

The first term reflects the within-cohort redistribution as a consequence of different shares in government bonds and in the taxes that finance the interest on the bonds. The second term reflects the across-cohort redistribution from changes in the price of safe consumption which is purchased from the previous generation by buying land.

We shall show in the next subsection that if $\mathrm{B} \leq \mathrm{aG}$, and demands for all goods are normal, then diversification raises the safe interest rate. Hence the expected utility of old savers falls when the policy is implemented, since the value of the land they are holding falls. In the absence of taxation for anything other than interest payments, a sufficient condition for the expected utility of young savers to rise is that the value of safe land is greater than the value of government bonds outstanding. As before, the increased exposure to risky stock and the rise in interest rates make workers better off. We summarize these effects as:

Proposition 4: Assuming the share of taxes of savers is at least as large as their share of bond holdings, B $\leq \mathrm{aG}$, and that demands are normal, then, starting from a trust fund invested exclusively in bonds, trust fund purchases of risky investments increase the expected utility of all workers (except the old at the time the policy is implemented, who are unaffected). The old savers are hurt. However, if in addition (aG B) $<p_{0}\left(L_{0}+L\right)$, then all other savers are helped. If, however, $(a G-B)>p_{0}\left(L_{0}+L\right)$, then all other savers are also hurt.

\section{Interest rate and aggregate savings}

Differentiating (22), we have:

$$
\begin{aligned}
& \mathrm{dp}_{\mathrm{J}} / \mathrm{dK}^{\mathrm{f}}=-1 /\left(\mathrm{C}_{\mathrm{p}}^{*}+\mathrm{C}^{*}{ }_{\mathrm{I}} \mathrm{aG}+\mathrm{K}_{\mathrm{p}}^{*}+\mathrm{K}_{\mathrm{I}}^{*} \mathrm{aG}+\left(\mathrm{L}_{0}+\mathrm{L}\right) /\left(1-\mathrm{p}_{\mathrm{J}}\right)^{2}\right) \\
& =-1 /\left(\mathrm{C}_{\mathrm{p}}^{*}+\mathrm{K}_{\mathrm{p}}^{*}+\left(\mathrm{B}+\mathrm{r}(\mathrm{B}-\mathrm{aG})+\left(\mathrm{p}_{0}+1\right) \mathrm{L}_{0}+\mathrm{pL}\right)\left(\mathrm{C}_{\mathrm{I}}^{*}+\mathrm{K}_{\mathrm{I}}^{*}\right)\right. \\
& \text { - } \left.(1+\mathrm{r})(\mathrm{B}-\mathrm{aG})\left(\mathrm{C}^{*}{ }_{\mathrm{I}}+\mathrm{K}_{\mathrm{I}}{ }_{\mathrm{I}}\right)-\left(\left(\mathrm{p}_{0}+1\right) \mathrm{L}_{0}+\mathrm{pL}\right)\left(\mathrm{C}^{*}{ }_{\mathrm{I}}+\mathrm{K}_{\mathrm{I}}{ }_{\mathrm{I}}\right)+\left(\mathrm{L}_{0}+\mathrm{L}\right) /\left(1-\mathrm{p}_{\mathrm{J}}\right)^{2}\right) \\
& =-1 /\left(\mathrm{C}_{\mathrm{p}}^{*}+\mathrm{K}_{\mathrm{p}}^{*}+\left(\mathrm{B}+\mathrm{r}(\mathrm{B}-\mathrm{aG})+\left(\mathrm{p}_{0}+1\right) \mathrm{L}_{0}+\mathrm{pL}\right)\left(\mathrm{C}_{\mathrm{I}}^{*}+\mathrm{K}_{\mathrm{I}}^{*}\right)\right. \\
& \text { - } \left.(1+\mathrm{r})(\mathrm{B}-\mathrm{aG})\left(\mathrm{C}^{*}{ }_{\mathrm{I}}+\mathrm{K}_{\mathrm{I}}{ }_{\mathrm{I}}\right)-\left(\left(\mathrm{L}_{0}+\mathrm{L}\right) /\left(1-\mathrm{p}_{\mathrm{J}}\right)\right)\left(\mathrm{C}^{*}{ }_{\mathrm{I}}+\mathrm{K}_{\mathrm{I}}{ }_{\mathrm{I}}\right)+\left(\mathrm{L}_{0}+\mathrm{L}\right) /\left(1-\mathrm{p}_{\mathrm{J}}\right)^{2}\right) \\
& =-1 /\left(\mathrm{C}_{\mathrm{p}}^{*}+\mathrm{K}_{\mathrm{p}}^{*}+\left(\mathrm{B}+\mathrm{r}(\mathrm{B}-\mathrm{aG})+\left(\mathrm{p}_{0}+1\right) \mathrm{L}_{0}+\mathrm{pL}\right)\left(\mathrm{C}_{\mathrm{I}}^{*}+\mathrm{K}_{\mathrm{I}}^{*}\right)\right. \\
& \left.-(1+\mathrm{r})(\mathrm{B}-\mathrm{aG})\left(\mathrm{C}_{\mathrm{I}}{ }_{\mathrm{I}}+\mathrm{K}_{\mathrm{I}}{ }_{\mathrm{I}}\right)-\left(\mathrm{L}_{0}+\mathrm{L}\right)\left(\left(1-\mathrm{p}_{\mathrm{J}}\right)\left(\mathrm{C}_{\mathrm{I}}{ }_{\mathrm{I}}+\mathrm{K}_{\mathrm{I}}^{*}\right)-1\right) /\left(1-\mathrm{p}_{\mathrm{J}}\right)^{2}\right) \text {. }
\end{aligned}
$$

The first terms add up to the compensated demands for first-period consumption and risky second-period consumption with respect to the price of safe second-period consumption and have a positive sum, as noted in the proof of proposition 2. The next term reflects the redistribution between savers and workers and is positive if savers have a larger share in taxes than in bonds and have normal demands. The final term reflects the intergenerational redistribution between old savers when the policy is implemented and later cohorts. It is also positive when the demand for safe second-period consumption is normal (which 
implies that $\left.\mathrm{C}_{\mathrm{I}}^{*}+\mathrm{K}_{\mathrm{I}}{ }_{\mathrm{I}}=1-\mathrm{p}_{\mathrm{J}} \mathrm{J}_{\mathrm{I}}^{*}<1\right)$. This also relies on the fact that the price of second period consumption is between zero and one when the safe interest rate is positive. Thus $\mathrm{dp}_{\mathrm{J}} / \mathrm{dK}^{\mathrm{f}}<0$, as was the case without land. The presence of long-lived assets decreases the sensitivity of interest rates to trust fund diversification, and thus decreases the size of the interest rate increase.

The effect of trust fund diversification on interest rates can be summarized as:

Proposition 5: Assuming the share of taxes of savers is at least as large as their share of bond holdings, and that demands are normal, then, trust fund purchases of risky investment increase the interest rate on government debt.

We note that the intertemporally additive structure of preferences implies that demand for first-period consumption is normal and the assumptions of decreasing absolute risk aversion and increasing relative risk aversion in second-period utility would imply that all three demands are normal.

The level of investment in short-term production possibilities, $\mathrm{K}^{\mathrm{f}}+\mathrm{K}^{*}-\mathrm{L}$, is equal to the endowment of young savers less their first-period consumption, less the amount spent on purchasing land less public debt minus the value of the Trust Fund. From the analysis leading to (23), we note that the derivative of the sum of first-period consumption and the value spent on land with respect to the price of second-period safe consumption (including the feedback through taxes) is

$$
\begin{aligned}
\mathrm{d}\left(\mathrm{C}^{*}+\mathrm{p}_{0} \mathrm{~L}_{0}+\mathrm{pL}\right) / \mathrm{dp} \mathrm{p}_{\mathrm{J}}= & \mathrm{C}_{\mathrm{p}}^{*}+\left(\mathrm{B}+\mathrm{r}(\mathrm{B}-\mathrm{aG})+\left(\mathrm{p}_{0}+1\right) \mathrm{L}_{0}+\mathrm{pL}\right) \mathrm{C}_{\mathrm{I}}^{*}-(1+\mathrm{r})(\mathrm{B}-\mathrm{aG}) \mathrm{C}_{\mathrm{I}}^{*} \\
& -\left(\left(\mathrm{L}_{0}+\mathrm{L}\right) /\left(1-\mathrm{p}_{\mathrm{J}}\right)\right) \mathrm{C}_{\mathrm{I}}^{*}+\left(\mathrm{L}_{0}+\mathrm{L}\right) /\left(1-\mathrm{p}_{\mathrm{J}}\right)^{2}
\end{aligned}
$$

The first two terms are the compensated cross elasticity of first-period consumption with respect to the price of second-period safe consumption. If the demand for bonds is normal, then this term is positive (Aura, Diamond, and Geanakoplos, 1999). With normality of demand for first period consumption, redistribution from savers to workers $(\mathrm{B} \leq \mathrm{aG})$ decreases consumption of young savers. While redistribution from older savers holding the assets at the time of implementation of the policy to later cohorts tends to increase first-period consumption, this is offset by the drop in the cost of purchasing land. That is, the last two terms together are positive, as we saw in the last step of the proof of proposition 5.

We state this as:

Proposition 6: Assuming that the share of taxes of savers is at least as large as their share of bond holdings and that the demand for bonds is increasing in wealth, then, trust fund purchases of risky investment increase aggregate real investment.

We note that the intertemporally additive structure of preferences implies that demand for first-period consumption is normal and the assumptions of decreasing absolute risk aversion and increasing relative risk aversion in second-period utility implies that the demand for bonds is normal.

With constant marginal returns in production, changes in the trust fund portfolio may alter the saver's portfolio because the interest rate may change, but not because fewer real investment opportunities are available for them. In the companion paper we examine a model with a fixed supply of infinitely-lived assets, but no short-lived assets at all, as well as the more general situation in which the expected returns to risky investment decline with the level of investment.

\section{Equilibrium with one-period safe assets and infinitely-lived assets}


We now consider the reverse case, where there are one-period safe real assets but no one-period risky assets. While not realistic, this displays an impact on land prices that is not present in the model above - the effect of diminished risky investment opportunities on land prices. In this case, the interest rate is determined by the return on safe real one-period assets. Thus the price of second period safe consumption and the price of safe land are both determined. Now, the price of risky land is determined by market clearance, reflecting both the given interest rate and the evaluation of risky consumption by savers. The price of risky land implicitly defines a price for risky second-period consumption, which we denote $\mathrm{p}_{\mathrm{K}}$, which is the difference between the price of risky land and the value of the safe second-period consumption available from future sale of the land.

$$
\mathrm{p}=\mathrm{p}_{\mathrm{K}}+\mathrm{p} /(1+\mathrm{r})
$$

or

$$
\mathrm{p}=(1+\mathrm{r}) \mathrm{p}_{\mathrm{K}} / \mathrm{r}=\mathrm{p}_{\mathrm{K}} /\left(1-\mathrm{p}_{\mathrm{J}}\right)
$$

The budget set presented in (2) now becomes:

$$
\begin{gathered}
\mathrm{V}=\operatorname{Max}_{1}\left[\mathrm{C}_{1}\right]+\mathrm{E}\left\{\mathrm{U}_{2}[\mathrm{~J}+\mathrm{RK}]\right\} \\
\text { s.t. } \mathrm{C}_{1}+\mathrm{p}_{\mathrm{J}} \mathrm{J}+\mathrm{p}_{\mathrm{K}} \mathrm{K}=\mathrm{W}-\mathrm{p}_{\mathrm{J}} \mathrm{T}
\end{gathered}
$$

The demand functions are now functions of the prices of both safe and risky second-period consumption. We concentrate on the demand for risky consumption, $\mathrm{K}^{*}\left[\mathrm{p}_{\mathrm{J}}, \mathrm{p}_{\mathrm{K}}, \mathrm{W}-\mathrm{p}_{\mathrm{J}} \mathrm{T}\right]$. In the absence of other sources of risky consumption, the only source of risky consumption is risky land, and each acre of risky land provides one unit of risky consumption. Hence K can be interpreted as the savers' demand for risky land. Letting $\mathrm{K}^{\mathrm{f}}$ represent the trust fund holdings of acres of risky land, the equation for risky land market clearance is:

$$
L=K^{f}+K^{*}\left[p_{J}, p_{K}, W-\left(1-p_{J}\right) a G\right] .
$$

With risky second-period consumption being a normal good, the demand is downward sloping and the price $\mathrm{p}_{\mathrm{K}}$ must rise in response to an increase in trust fund holdings of land in order to clear the market. From the connection between $\mathrm{p}_{\mathrm{K}}$ and the price of risky land derived above, we conclude that the price of risky land also rises. We note that the assumption of decreasing absolute risk aversion implies that the demand for risky second-period consumption has a positive income effect.

We state this as:

Proposition 7: Assuming the presence of safe real one-period investments, but no risky real one-period investments, and that demand for risky second period consumption is normal, then, trust fund purchases of risky investment increase the price of risky land.

With a rise in the price of risky land, the expected utility of old savers rises when the policy is implemented, since the value of the land they are holding rises. In turn, this lowers the expected utility of young savers and those in future cohorts. The expected utility of workers is increased in the same way as above.

Aggregate investment in safe real one-period investments equals the first-period wealth of savers minus what they spend on land and bonds, $W-C^{*}-p_{0} L_{0}-p\left(L-K^{f}\right)-B=W-C^{*}-p_{0} L_{0}-p L-B+p K^{f}$. Since $G-F_{0}=$ $\mathrm{B}-\mathrm{pK}^{\mathrm{f}}$ is fixed, and since trust fund diversification raises $\mathrm{p}$, it follows that investment in safe assets must go down unless $\mathrm{C}^{*}$ declines by more than $\mathrm{pL}$ rises, which we show in our companion paper is impossible. 
We state this as:

Proposition 8: Assuming the presence of safe real one-period investments, but no risky real one-period investments, and that demands are normal, then, trust fund purchases of risky investment decrease investment.

With constant returns in short-run risky production, changes in the trust fund portfolio may alter the saver's portfolio because the interest rate may change, but not because fewer real investment opportunities are available for them. Without any short-run risky investment the impact on available opportunities is particularly important. In the companion paper we examine models with a fixed supply of infinitely-lived assets, but no short-lived assets at all and models with decreasing expected returns to risky investment when there is more investment. These models are more complex than those analyzed in this paper since they have two endogenous prices rather than just one.

\section{Defined Benefits}

The model we have employed has a defined contribution social security system for analytical convenience. Within the structure of the model that has one-period risky investment, but no one-period safe investment, it is straightforward to consider a defined benefit system, provided that the quantity of bonds available to savers is stationary. This will be the case when the variation in the trust fund in response to the combination of random portfolio return and payroll tax and benefit rules is fully allocated to risky investments. In this case, the environment of savers does not change if the defined contribution system is changed to a defined benefit system. Thus, we can analyze payroll tax and benefit planning in isolation; without any feedbacks on savers, equilibrium prices do not change. The new element is to smooth benefits, while recognizing the need to satisfy a nonnegativity constraint should there be a prolonged period of low returns. ${ }^{16}$

In the presence of random returns on a nontrivial portion of the trust fund, it is necessary to recognize the probability that the portion of the trust fund invested in risky assets would become negative if both benefits and taxes were unchanged. Thus, a defined benefit system must be changed from time to time. The policies that determine such change need to be modeled in order to consider the value of smoothing that comes from defined benefits. In the context of a model with randomness in other aspects of the economic and demographic environment of the social security system, the change in uncertainty from a diversified portfolio would not be such a salient change in the system. ${ }^{17}$

A simple approach to adapting the model would leave taxes and the trust fund holdings of government bonds unchanged. The level of benefits would adapt to the level of the trust fund, thereby rising with the return on the portfolio, as does a defined contribution system, but not rising dollar-fordollar, as the returns get spread over future cohorts. In this way the benefits of a cohort would depend on the realized returns over a longer period of time (than just one period). With a plausible stochastic process for the return on capital, this would raise expected utility for future generations, measured as of the time of implementation of the policy. Thus the gain from a diversified portfolio becomes larger with a good policy for determining benefits. Similarly the analysis could be extended to include varying tax rates.

\footnotetext{
${ }^{16}$ While other cases can be analyzed as well, the analysis would be more complicated.

${ }^{17}$ If a defined contribution system is to fulfill its social purpose, it will also need periodic change in response to economic and demographic developments.
} 


\section{Concluding remarks}

We have considered the implications of changing trust fund portfolio policy away from $100 \%$ government debt. In a model with only short-term assets, when a safe real asset is held in equilibrium and production is linear, such a policy change yields a (weak) Pareto improvement if workers are not so risk averse as to want to hold zero risky assets. Moreover, by substituting risky for safe real investment, expected output rises.

When there is not a safe real asset, then there is an additional effect - a change in the rate of interest on government debt, which in turn requires a change in taxes to service the debt. If this change does not redistribute income between savers and workers, the finding of a (weak) Pareto gain continues to hold. However, when the improved portfolio for workers is combined with redistribution from taxpayers to interest recipients, then the simple policy analyzed here does not necessarily cause a Pareto gain. If the redistribution is from savers to workers, then there is an additional gain, beyond the improved portfolio for workers, to any social welfare function that values such redistribution.

If savers pay more in income taxes to finance debt payments than they receive in interest on the government debt they themselves hold, then diversification raises the safe interest rate, increases aggregate investment, and indeed redistributes wealth from savers to workers, under plausible preference assumptions.

Adding inelastically-supplied, infinitely-lived assets to the model introduces a source of intergenerational redistribution. Provided that savers have a larger share in marginal taxes to finance interest payments than in bond holdings, trust fund diversification causes a rise in the interest rate and a decline in the price of the long-lived assets. This price change, in turn, causes a transfer from elderly savers holding the assets when the portfolio changes, to future savers who now find a lower price for these assets. Again, there is an increase in real investment under plausible preference parameters.

This paper has assumed that the production opportunities are linear - neither the wage nor the expected return on investment were changed in the new equilibrium induced by a change in the trust fund portfolio. Yet, in the new equilibrium there is an increase in real investment under plausible assumptions. This would increase the wage and decrease the expected return on real investment, in a model with endogenous wages and endogenous marginal returns to risky investment. A fall in the expected return on real investment tends to increase the price of inelastically-supplied, infinitely-lived assets with unchanging returns, and can reverse the direction of redistribution between savers who are elderly when the policy is implemented, and later cohorts. Such a model is explored in our companion paper.

There are four points to make relative to the current policy debate. ${ }^{18}$ First, unlike some assertions, the heterogeneity of the population implies that trust fund portfolio choice does have real effects on the economy. Second, while it is appropriate to be concerned about the risk associated with a change in portfolio policy, it seems to us unlikely that workers are so risk averse that a portfolio completely invested in Treasury bonds is optimal. This point is reinforced by the ability of the government to spread risk over successive cohorts since Social Security is a defined benefit system. That is, if a defined benefit system is well-run, there is a stronger case for trust fund investment in private securities than in the models analyzed here which assumed a defined contribution system. Third, the marginal social benefit to diversification declines as the level of diversification increases (and as workers are exposed to more risk), which puts a limit on the total amount of socially desirable diversification.

\footnotetext{
${ }^{18}$ For more discussion of Trust Fund investment, see Munnell and Balduzzi (1998) and Panel on Privatization of Social Security (1998).
} 
Diversification increases the value of social security, but there is nothing in our analysis that suggests a reasonable level of diversification alone is sufficient to restore actuarial balance to Social Security. Lastly, the models considered here have substituted equity investment for bond investment, holding constant the level of funding of Social Security. Many proposals for investment in stocks, whether through the trust funds or through individual accounts, use stock investments as a reason to increase or decrease the financing of Social Security (at least in the short run) relative to what might be proposed without such investment. Such a change involves intergenerational redistribution that is not incorporated in the analysis in this paper. ${ }^{19}$ Our analysis does apply, however, to proposals that would substitute a portfolio change for cuts in future benefits.

\section{References}

Ameriks, John, and Stephen P. Zeldes, in progress, How Do Household Portfolio Shares Vary with Age?

Aura, Saku, Peter Diamond and John Geanakoplos, 1999, Savings in a two-period two-asset model, unpublished.

Bohn, Henning, 1997, Risk Sharing in a Stochastic Overlapping Generations Economy, unpublished, University of California at Santa Barbara.

Bohn, Henning, 1998, Social Security Reform and Financial Markets, in Federal Reserve Bank of Boston Conference on Social Security Reform.

Diamond, Peter, 1997, Macroeconomic Aspects of Social Security Reform, Brookings Papers on Economic Activity, 2.

Diamond, Peter, and John Geanakoplos, Social Security Investment in Equities II: Decreasing Returns

Diamond, Peter and Menahem Yaari, 1972, Implications of the Theory of Rationing for Consumer Choice Under Uncertainty, American Economic Review, LXII (3), June, 333-343.

Financial Economists' Roundtable, 1998, Statement on Social Security, unpublished.

Fischer, Stanley, 1972, Assets, Contingent Commodities, and the Slutsky Equations, Econometrica, 40, 2, March, 371-85.

Forbes, Steve, 1996, How to Replace Social Security, The Wall Street Journal, December 18.

Geanakoplos, John, Olivia S. Mitchell, and Stephen P. Zeldes, 1998, Would a Privatized Social Security System Really Pay a Higher Rate of Return?, in Arnold, Graetz, and Munnell, eds., 1998, Framing the Social Security Debate, National Academy of Social Insurance, Washington, D.C.: Brookings Institution Press.

Geanakoplos, John, Olivia S. Mitchell, and Stephen P. Zeldes, 1999, Social Security Money's Worth, in Mitchell, Myers, and Young, eds., 1999, Prospects for Social Security Reform, University of Pennsylvania Press, Philadelphia.

\footnotetext{
${ }^{19}$ See Smetters, 1997.
} 
Greenspan, Alan, 1997, Testimony before the Task Force on Social Security of the Committee on the Budget, U. S. Senate, November 20.

Kennickell, Arthur, Martha Starr-McCluer, and Annika E. Sunden, 1997, Family Finances in the U.S.: Recent Evidence from the Survey of Consumer Finances, Federal Reserve Bulletin, January.

Mitchell, Olivia S., and James F. Moore, 1997, Retirement Wealth Accumulation and Decumulation: New Developments and Outstanding Opportunities, Working Paper 97-12, The Wharton School, University of Pennsylvania.

Moore, Stephen, 1997, Prepared Testimony on the Future of Social Security for This Generation and the Next, House Ways and Means Committee, Social Security Subcommittee, 105 Cong. 1 sess. June 24. Washington: Government Printing Office.

Munnell, Alicia H., and Pierluigi Balduzzi, 1998, Investing the Trust Fund in Equities, unpublished, Boston College.

Panel on Privatization of Social Security, National Academy of Social Insurance, 1998, Evaluating Issues in Privatizing Social Security, Washington: National Academy of Social Insurance.

Smetters, Kent, 1997, Investing the Social Security Trust Fund in Equity: An Options Pricing Approach, Technical Paper 1997-1, Congressional Budget Office, Macroeconomic Analysis and Tax Analysis Divisons.

Social Security Administration, 1996, Annual Statistical Supplement to the Social Security Bulletin. 